\title{
ArcheoSciences
}

Revue d'archéométrie

\section{Technological study of pre-Columbian bimetallic discs from Monte Alban, Oaxaca, Mexico}

Étude technologique des disques bimétalliques précolombiens de Monte Alban, Oaxaca, Mexique

Gabriela Peñuelas Guerrero, Jannen Contreras Vargas, José Luis Ruvalcaba Sil and Ángel García Abajo

\section{(2) OpenEdition}

\section{Journals}

Electronic version

URL: http://journals.openedition.org/archeosciences/2355

DOI: 10.4000/archeosciences.2355

ISBN: 978-2-7535-1598-7

ISSN: $2104-3728$

\section{Publisher}

Presses universitaires de Rennes

\section{Printed version}

Date of publication: 31 December 2009

Number of pages: $299-302$

ISBN: 978-2-7535-1181-1

ISSN: 1960-1360

\section{Electronic reference}

Gabriela Peñuelas Guerrero, Jannen Contreras Vargas, José Luis Ruvalcaba Sil and Ángel García Abajo, «Technological study of pre-Columbian bimetallic discs from Monte Alban, Oaxaca, Mexico », ArcheoSciences [Online], 33 | 2009, Online since 10 December 2012, connection on 03 May 2019. URL : http://journals.openedition.org/archeosciences/2355; DOI : 10.4000/archeosciences.2355 


\title{
Technological study of pre-Columbian bimetallic discs from Monte Alban, Oaxaca, Mexico
}

\author{
Étude technologique des disques bimétalliques précolombiens de Monte Alban, \\ Oaxaca, Mexique
}

\author{
Gabriela Peñuelas Guerrero*, Jannen Contreras Vargas*, \\ José Luis Ruvalcaba Sil ${ }^{* *}$ and Ángel García Abajo*
}

\begin{abstract}
One of the most remarkable examples of metalwork from Mesoamerica is the collection from Monte Alban's Tomb 7. Among its items, we encounter extraordinary examples of bimetallic artefacts; a pair of solar representations whose main particularity is that they are formed by two different alloy sheets: one rich in silver and the other rich in gold. The silver-rich zones show deterioration characterized by brittleness, fractures and the loss of some fragments; this fragility is apparently due to dislocations caused by repeated hammering and insufficient annealing during the manufacturing process. Because sampling of the original items was not allowed, test specimens were prepared replicating the manufacturing techniques and alloy compositions, based on data previously obtained by X-ray Fluorescence Analysis of the original pieces. Examination of these test specimens was undertaken in order to understand the thermodynamic behaviour of the metallic microstructure and its relation to the alteration processes. Samples of each alloy were then taken and analyzed by metallographic methods.

Résumé: Un des plus remarquables exemples du travail du métal en Mésoamérique est l'ensemble trouvé dans la Tombe 7 de Monte Alba. Parmi ces objets, certains sont des exemples extraordinaires de productions bimétalliques, comme une paire de représentations solaires dont la principale particularité est l'utilisation de deux feuilles d'alliages différents : un riche en argent et l'autre riche en or. Les régions riches en argent montrent une dégradation caractérisée par des cassures, fractures et perte de fragments; cette fragilité est apparemment due aux dislocations causées pendant leur fabrication par des coups de marteau répétés avec une chauffe insuffisante. Comme il est impossible de prélever des objets originaux, des analogues ont été préparés en utilisant les mêmes techniques de fabrication et des alliages identiques, révélés par les analyses réalisées précédemment par FX sur les pièces originales. L'examen des analogues a été réalisé de façon à comprendre le comportement thermodynamique de la microstructure métallique et son rapport aux procédés d'altération. Des échantillons de chacun des alliages ont été prélevés pour effectuer une analyse métallographique.
\end{abstract}

Keywords: Bimetallic artefacts, gold alloys, silver alloys, metallography, X-ray fluorescence.

Mots-clés : objets bimétalliques, alliages d'or, alliages d'argent, métallographie, FX.

\section{INTRODUCTION}

In October 2007, part of the jewellery collection which constitutes the offering of Tomb 7 of Monte Alban,
Oaxaca, Mexico, was analyzed by means of portable X-ray Fluorescence (XRF) with the purpose of characterizing the alloys and manufacturing techniques, and of obtaining relevant information on the alteration phenomena,

* Escuela Nacional de Conservación, Restauración y Museografia-INAH - General Anaya 187 Col. San Diego Churubusco, Coyoacán, México D.F. CP. 04120., Mexico. (gabrielapenuelas@gmail.com), (jannencontreras@gmail.com)

** Instituto de Física, Universidad Nacional Autónoma de México - Apdo. Postal 20-364, México D.F 01000, Mexico. (sil@fisica.unam.mx) 
in order to prepare a conservation proposal (Peñuelas Guerrero, 2008).

This offering represents one of the most representative, varied and rich metalworking traditions of the Mixtec area, and even of the entire Mesoamerican area (Caso, 1969). Even though some analyses of a few gold objects were carried out before (Camacho Bragado, 2005), this was the first one using portable XRF to obtain elemental composition data, enabling one third of the entire metalwork collection to be studied. Moreover, this analytical approach was the first one employed for characterizing the silver alloys of the artefacts.

Among the jewellery items, there are two small and unique artefacts with solar representations in relief, made with two different alloys: one rich in silver and the other rich in gold. These pieces are known as bimetallic discs (Fig. 1).

In Mexico, besides these pieces, only one other bimetallic pendant originating from Teotitlan del Camino, Oaxaca (Fig. 2) is known. It is conserved in the Museo Nacional de Antropologia e Historia - INAH (Carmona Macias, 1997). The main difference between the Monte Alban discs and the Teotitlan pendant is that the pendant was clearly made by lost wax casting while, because of their thinness, the discs were probably made by hammering.

The production of bimetallic items with gold in preColumbian America is not as uncommon as we may think, but platinum was used instead of silver. Fray Bernardino de Sahagun, one of the most representative chroniclers of New Spain, describes the extraordinary objects that Aztecs were able to make by combining gold and silver (Sahagun, 2000).

The first archaeologist to analyze the manufacture technique of the bimetallic discs was Easby (Caso, 1969), who proposed that the discs were made by hammering two different sheets together: one of an alloy rich in silver, and the other of an alloy rich in gold, achieving a diffusion boun-

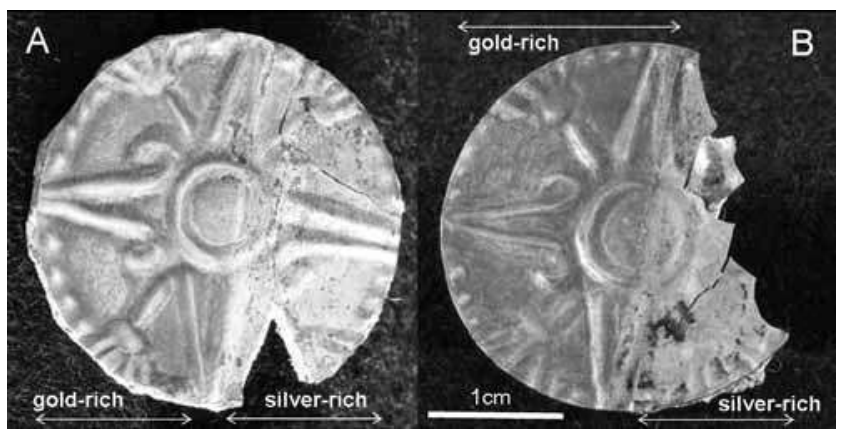

Figure 1: (See colour plate) The bimetallic discs from Tomb 7 of Monte Alban, Oaxaca, Mexico.

Figure 1 : (Voir planche couleur) Les disques bimétalliques de la Tombe 7 de Monte Alban, Oaxaca, Mexique.

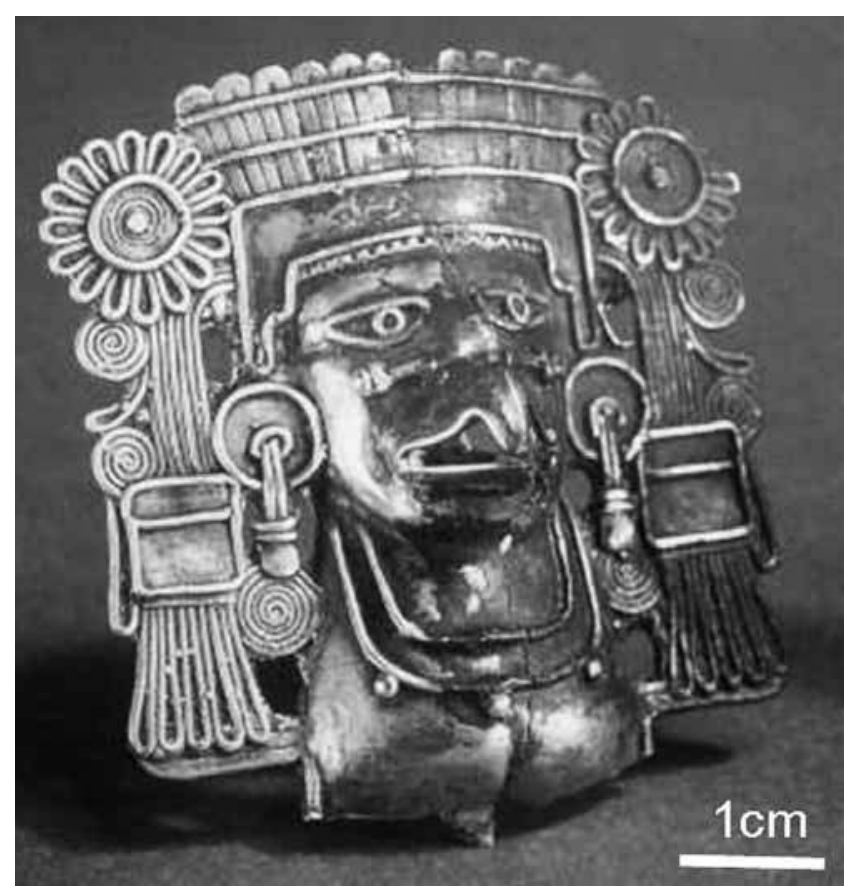

Figure 2: (See colour plate) The Teotitlan del Camino, Oaxaca, bimetallic pendant.

Figure 2: (Voir planche couleur) Le pendentif bimétallique Teotitlan del Camino, Oaxaca.

dary of the foils. Besides the unusual manufacture technique, the bimetallic discs present a specific conservation problem: the silver-rich zones are brittle, show fractures and have lost some fragments; this fragility is apparently due to dislocations caused by repeated hammering with insufficient annealing. The actual study was carried out to understand their deterioration phenomena as well.

\section{Methodology}

Previous XRF measurements of the two discs provided information on their composition. For the first disc, the mean composition of the part rich in gold is $85.8 \% \mathrm{Au}, 13.7 \%$ $\mathrm{Ag}$ and $0.6 \% \mathrm{Cu}$, while the silver-rich alloy section has an average composition of $91.1 \% \mathrm{Ag}, 6.4 \% \mathrm{Au}$ and $2.5 \% \mathrm{Cu}$ (Peñuelas Guerrero, 2008). For the second disc, the average compositions for the gold and silver sections are $81 \% \mathrm{Au}$, $18.2 \% \mathrm{Ag}, 0.7 \% \mathrm{Cu}$, and $91.3 \% \mathrm{Ag}, 5.5 \% \mathrm{Au}$ and $3.2 \% \mathrm{Cu}$, respectively. Based on Easby's hypothesis and knowing the elemental composition of each alloy from XRF measurements, replica alloys were designed to test his hypothesis.

The first step involved the reproduction of the alloys with a mean composition about $85 \% \mathrm{Au}, 14 \% \mathrm{Ag}$ and $1 \% \mathrm{Cu}$, 
and $91 \% \mathrm{Ag}, 6 \% \mathrm{Au}$ and $3 \% \mathrm{Cu}$, and the casting of each part individually. Subsequently, the homogeneity of the elemental composition of the replicas was verified using a portable XRF spectrometer with a Mo X-ray tube with a voltage of $45 \mathrm{kV}$, a current of $0.2 \mathrm{~mA}$, and a CT detector. The exciting X-ray beam had a diameter of $1.5 \mathrm{~mm}$ on the sample surface and each measurement lasted $30 \mathrm{sec}$.

Once the foils were reproduced, we proceeded to try to join them by hammering and heating. Although we were unable to join them according to this procedure, after obtaining a similar thickness to that of the original discs, we proceeded to take samples of each alloy for metallographic examination.

\section{Results}

After a long hammering and annealing process, it proved impossible to join the two sheets, due to their different behaviour. Without soldering, higher temperatures were required to join them, but the different melting points of each alloy (the gold-rich alloy melts at $1010{ }^{\circ} \mathrm{C}$ while the silver-rich alloy melts at $954{ }^{\circ} \mathrm{C}$ ), in combination with the rapid heat diffusion caused by the limited thickness of the foil $(0.8 \mathrm{~mm})$, caused the silver-rich alloy to begin to fuse instead of joining to the gold one.

The fusing of the silver alloy was verified by means of metallographic analysis; while the structure of the gold alloy showed crystals and macles characteristic of cold work, the silver-rich alloy had a cast-like structure, even though both metals were worked at the same temperature (Fig. 3).

\section{Conclusion}

Based on observations of the tests performed on the replica alloys and the study of the other existing bimetallic artefact, the Teotitlan pendant made by lost wax casting, a hypothesis regarding the manufacture of the Monte Alban bimetallic discs is proposed. The Teotitlan pendant was probably cast by first casting the higher melting point alloy and then completing the mould with the other lower melting point alloy. We believe that the alloys of the bimetallic discs were likely cast in a similar manner and were then joined mechanically, with heat. Afterwards, the goldsmith must have hammered the cast objects to obtain the desired thickness, size and design. The beating and heating should have strengthened the join and produced a slight silver diffusion into the gold-rich alloy.

We can conclude that the brittleness of the silver-rich alloy is due to an excess of dislocations resulting from the different behaviour of the two alloys that were cold worked (hammered) together. Nevertheless, the next step of this experiment is to reproduce the lost wax casting and hammering in order to obtain further information regarding the deterioration phenomena.

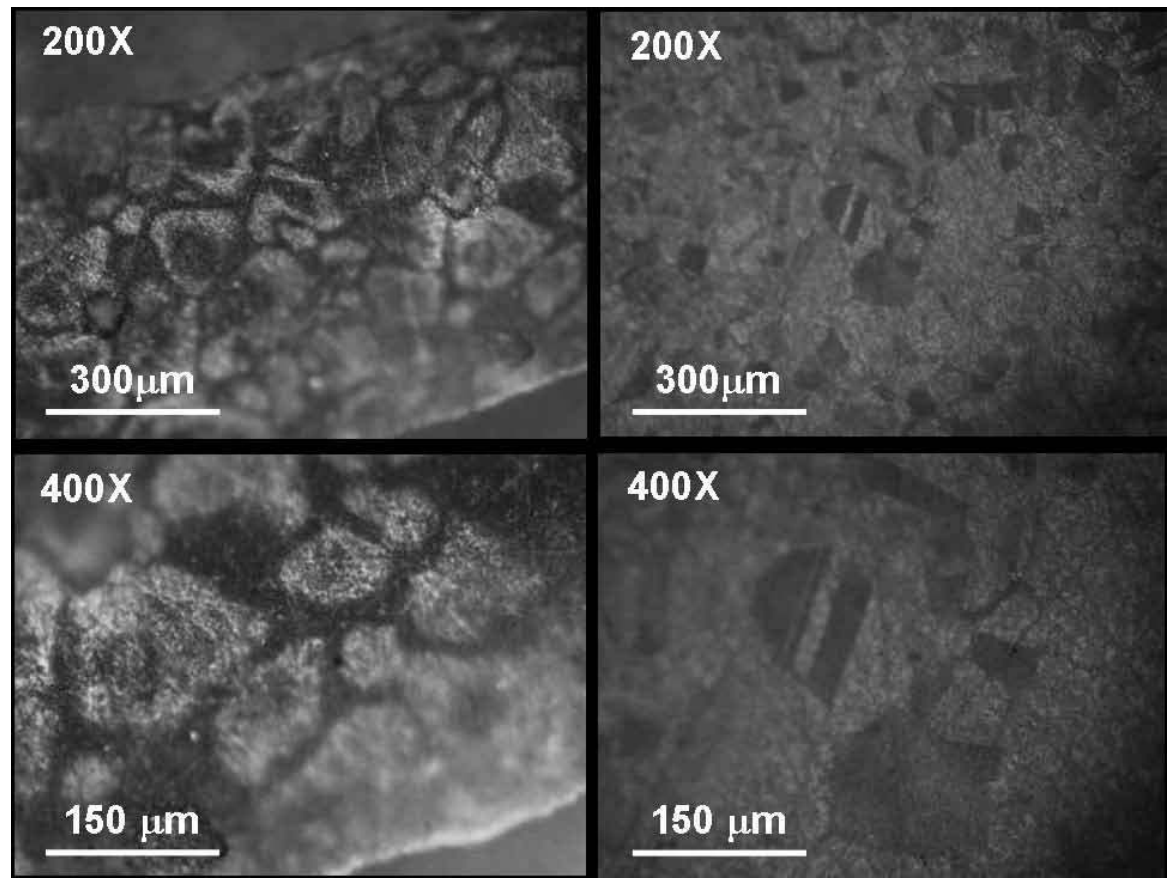

Figure 3: (See colour plate) Metallographic plates of the silver and gold alloys made for the bimetallic replica test (200X and 400X).

Figure 3: (Voir planche couleur) Planches métallographiques des alliages d'argent et d'or réalisées pour effectuer les analogues bimétalliques (200X and 400X). 


\section{Acknowledgements}

This research is part of the MOVIL project Non destructive methodologies for the study of the Mexican cultural heritage, with the financial support of the CONACyT Mexico U49839-R.

\section{References}

Caso, A., 1969. El Tesoro de Monte Albán. Memorias del Instituto Nacional de Antropologia e Historia III. México, Instituto Nacional de Antropologia e Historia.

Carmona Macias, M., 1997. Entre Crisoles y Dioses: La orfebreria prehispánica de Oaxaca, in M. Dalton Palomo, V. Loera y Chávez Castro (eds.), Historia del Arte de Oaxaca, Arte
Prehispánico, vol. 1. Oaxaca, México, Gobierno del Estado de Oaxaca, Instituto Oaxaqueńo de las Culturas, 286-307.

Camacho Bragado, A., Ortega, M., Velasco, M. and JoséYACAMÁn, M., 2005. A microstructural study of gold treasure from Monte Alban's Tomb 7. Journal of the Minerals, Metals and Materials Society 57(7): 19-24.

Peńuelas Guerrero, G., 2008. Caracterización por Medio de Análisis Instrumentales de los Materiales Constitutivos de la Orfebreria de la Tumba 7 de Monte Albán, Oaxaca. México: Esc. Nal. de Restauración. Conservación. y Museografía, Instituto Nacional de Antropologia e Historia.

Sahagun, B., 2000. Historia General de las Cosas de la Nueva España. México, Conaculta, Colección Cien de Mexico. 